\title{
Perilaku Penyerangan NPC Berbasis Fuzzy Sugeno pada Game Action-RPG Bertema Sejarah Geger Pacinan
}

\author{
NPC Attack Behaviour Based On Fuzzy Sugeno in Action-RPG Game \\ with Theme of Geger Pacinan History
}

\author{
Muhammad Adhie Darmawan*1, Hanny Haryanto ${ }^{2}$, Yuniarsi Rahayu ${ }^{3}$ \\ ${ }^{1,2,3}$ Program Studi Teknik Informatika, Fakultas Ilmu Komputer, Universitas Dian Nuswantoro \\ E-mail: *1'muhammad.adhi.2015@gmail.com, ${ }^{2}$ hanny.haryanto@dsn.dinus.ac.id, \\ 3yuniarsi.rahayu@dsn.dinus.ac.id
}

\begin{abstract}
Abstrak
Sejarah merupakan suatu hal yang penting untuk dipelajai karena sangat bermanfaat dalam membangun nilai moral suatu bangsa. Di kota Semarang terdapat peristiwa sejarah yang disebut sebagai Geger Pacinan. Namun sayangnya peristiwa tersebut masih belum banyak dikenal oleh kalangan masyarakat karena kurangnya minat untuk mempelajari sejarah. Permainan dapat digunakan sebagai media pembelajaran dan pengenalan sejarah karena sifatnya yang interaktif sehingga membuatnya menjadi lebih menarik untuk dipelajari. Dalam sebuah permainan terdapat berbagai aspek yang membuatnya menjadi lebih menantang seperti karakter NPC (Non-Player Character). Pada dasarnya karakter NPC tidak dijalankan oleh pemain namun dikendalikan oleh sistem komputer. Hal tersebut membuatnya bersifat monton dan kurang dinamis. Metode fuzzy sugeno digunakan untuk mengendalikan perilaku yang dilakukan oleh karater musuh atau NPC dalam bertaung melawan pemain pada permainan action-RPG. Parameter masukan yang digunakan dalam sistem fuzzy adalah health point musuh, health point pemain dan nilai bahaya. Hasil akhir dari penelitian ini adalah sistem fuzzy dapat menghasilkan nilai aksi yang lebih dinamis sehingga karakter NPC dapat melakukan aksi yang sesuai dengan situasi yang dihadapi
\end{abstract}

Kata Kunci - Fuzzy Sugeno, Geger Pacinan, Non-Player Character, Permainan Action-RPG, Perilaku Menyerang

\begin{abstract}
History is an important thing to learn because it is very useful to building the moral value of a nation. In the city of Semarang, there is a historical event called Geger Pacinan. But unfortunately, that event is still not widely known by the community because of lack of interest to learn history. The game can be used to learning and to introduce history because of it is interactive so that makes it more interesting to learn. In a game, there are various aspects that make it more challenging like the character of NPC (Non-Player Character). Basically, the NPC character is not controlled by the player but it controlled by the computer system. It makes the game monotonous and static. The Sugeno fuzzy method is used to control the attack behavior performed by enemy character or NPC in a fight against a player in an action-RPG game. The input parameters used in the fuzzy system are enemy's health point, player's health point and danger value. The final result of this research is the fuzzy system can generate more dynamic action value so that the NPC character can perform the action according to the situation.
\end{abstract}

Keywords - Sugeno Fuzzy, Geger Pacinan, Non-Player Character, Action-RPG Game, Attack Behaviour 


\section{PENDAHULUAN}

Sejarah merupakan suatu peristiwa yang sudah terjadi di masa lampau yang disusun berdasarkan rangkaian peninggalan dari berbagai peristiwa [1]. Dari sisi lain sejarah dapat dipandang sebagai kejadian yang dialami pada masa kini merupakan kelanjutan dari kejadian yang terjadi di masa lampau. Memahami sejarah pada manusia merupakan hal yang sangat penting dalam membina budaya bangsa. Di samping itu, mempelajari sejarah juga mempunyai fungsi sosiokultural dan dapat membangkitkan kesadaran historis. Sehingga dari kesadaran historis ini akan berkembang menjadi kesadaran nasionalis [2].

Di Kota Semarang terdapat peristiwa bersejarah yang sangat penting, salah satunya yaitu Geger Pacinan atau disebut dengan Tragedi Angke. Peristiwa ini bercerita tentang persekutuan antara etnis jawa dan etnis cina (tionghoa) dalam melawan tentara VOC [3]. Peristiwa tersebut merupakan pembantaian terhadap masyarakat tionghoa oleh VOC yang dipicu oleh masalah perdagangan. Banyaknya korban masyarakat tionghoa yang tewas dalam peperangan tersebut yang pada akhirnya memicu etnis jawa untuk ikut turun tangan membantu masyarakat tionghoa untuk bersatu menyerang markas VOC yang salah satunya berada di kota Semarang. Namun sayangnya peristiwa bersejarah tersebut masih kurang dikenal oleh kalangan masyarakat, terutama di Kota Semarang. Berdasarkan survey terhadap 103 orang menunjukan bahwa sebanyak $62,1 \%$ orang tidak mengerti tentang sejarah tersebut, sedangkan sebanyak $31,1 \%$ orang pernah mendengar dan hanya 6,8\% orang yang mengetahui.

Industri game saat ini telah menjadi industri yang banyak digemari berbagai kalangan salah satunya di Indonesia. Mata pelajaran sejarah saat ini menjadi kendala untuk pelajar di Indonesia. Banyak dari siswa yang kurang tertarik untuk mempelajari sejarah karena dianggap membosankan [4]. Game dapat dijadikan sebagai alternatif dalam media pembelajaran untuk mengenalkan sejarah dengan cara yang menyenangkan. Perancangan game edukasi dengan mengangkat tema sejarah di Indonesia pernah dilakukan oleh Andry Chowanda dan Yen Lina Prasetio [4]. Game dengan tipe RPG (Role Playing Game) dengan judul "The Keris of Vengeance” menceritakan tentang tokoh Ken Arok dan Buto Ijo.

Dalam sebuah permainan terdapat beberapa elemen penting untuk membangun gameplay experience atau pengalaman bermain. Berdasarkan penelitian yang dilakukan oleh Ricardo Lopes dan Rafael Bidarra komponen Adaptivity Challenges dalam permainan ada 5 bagian yaitu game world, mechanic, NPC/AI, narratives dan scenarios/quest [5]. Salah satu komponen yang sangat penting dalam permainan adalah AI (artificial Intelegence) atau dikenal dengan kecerdasan buatan dan NPC (Non Player Character). NPC merupakan suatu objek atau karakter yang tidak dikendalikan oleh pemain, namun dijalankan oleh komputer [6]. Karena tidak dapat dikendalikan, hal tersebutlah yang terkadang membuat karakter NPC cenderung bersifat monoton dan mudah untuk diprediksi sehingga permainan akan cenderung membosankan. Permainan akan menjadi lebih menarik dan menantang apabila karakter NPC memiliki perilaku yang realistis dan tidak monoton [7]. Kecerdasan buatan merupakan bidang ilmu yang turut berkontribusi dalam produksi game terutama dalam hal interaksi antara NPC dengan manusia (pemain) [8].

Dalam keterkaitannya dengan game, penelitian mengenai logika fuzzy pernah dilakukan oleh Kristo Radion Purba, Rini Nur Hasanah dan M. Aziz Muslim yang diterapkan pada karakter NPC [9]. Pada penelitian tersebut menggunakan fuzzy sugeno ordo 0 untuk menentukan perilaku pada karakter NPC dengan probabilitas tertentu. Kelebihan dari penggunaan fuzzy sugeno ordro 0 adalah karena dari proses mesin inferensi yang dihasilkan berupa konstanta atau nilai tegas. Selain itu perhitungan matematis dan komputasi yang sederhana menbuatnya lebih efisien. Hal tersebutlah yang mendasari penggunaan fuzzy sugeno ordo 0 sehingga dapat mewakili aksi yang dilakukan pada suatu karakter [9]. Penelitian selanjutnya menggunakan parameter HP dalam penelitiannya sebagai masukan dalam sistem fuzzy [10] [11].

Beberapa metode kecerdasan buatan pada game juga diterapkan oleh [12] dengan menggunakan Fuzzy State Machine, kemudian [13] yang menerapkan algoritma Negamax dan Alpha-Beta Search pada permainan Gomoku. [14] menggunakan Finite State Machine untuk mengatur perilaku reward pada game pendidikan. 
Pada penelitian ini akan dirancang sebuah permainan dengan tipe Action RPG yang menerapkan logika fuzzy sugeno ordo 0 pada karakter NPC dengan mengangkat tema sejarah Geger Pacinan. Logika fuzzy akan digunakan untuk menentukan pola penyerangan karakter NPC saat menghadapai lawan dalam petarungan 1 lawan 1 sehingga karakter NPC dapat menyerang target dengan menyesuaikan berbagai kondisi.

\section{METODE PENELITIAN}

Penelitian ini menggunakan Fuzzy Sugeno, dimana hasil dari proses hasil keluaran pada mesin inferensi berupa nilai konstanta atau persamaan linear. Terdapat 2 model dalam metode sugeno yaitu:

1. Model Fuzzy Sugeno Ordo 1

Bentuk umum model sugeno ordo 1 dapat dilihat pada persamaan (1):

$$
\text { IF }\left(x_{1} \text { is } A_{1}\right) \bullet\left(x_{2} \text { is } A_{2}\right) \bullet \ldots \bullet\left(x_{n} \text { is } A_{n}\right) \text { then } z=f(x, y)
$$

Dengan nilai dari z dapat berupa persamaan (2):

$$
z=p_{1} * x_{1}+\ldots+p_{n} * x_{n}+q
$$

2. Model Fuzzy Sugeno Ordo 0

Bentuk umum model sugeno ordr 0 dapat dilihat pada persamaan (3):

$$
\text { IF }\left(x_{1} \text { is } A_{1}\right) \bullet\left(x_{2} \text { is } A_{2}\right) \bullet \ldots \bullet\left(x_{n} \text { is } A_{n}\right) \text { then } z=k
$$

Dengan nilai k adalah konstanta tegas (crisp).

Pada tahap mesin inferensi, fungsi implikasi yang digunakan adalah fungsi MIN untuk mendapatkan nilai $\alpha$-predikat pada masing-masing aturan. Kemudian masing-masing nilai predikat tersebut digunakan untuk menghitung hasil dari inferensi secara tegas (crisp) pada tiaptiap aturan $z_{1}, z_{2}, z_{3} \ldots z_{n}$. Karena hasil dari mesin inferensi sugeno berupa nilai tegas, maka kurva yang digunakan adalah kurva singleton.

Nilai tegas dari proses defuzzyfikasi didapatkan dengan metode rata-rata yaitu dengan menggunakan rumus (4):

$$
z=\frac{a_{1} z_{1}+a_{2} z_{2}}{a_{1}+a_{2}}
$$

\subsection{Penentuan Aksi Karakter NPC}

Metode yang akan diterapkan dalam penelitian ini adalah fuzzy sugeno ordo 0 dengan alur proses yang terdapat pada Gambar 1. Pada tahap ini dilakukan proses untuk mendapatkan suatu nilai tertentu yang nantinya nilai tersebut akan digunakan untuk menentukan aksi yang diakukan oleh karakter NPC. Beberapa aksi yang dilakukan adalah menyerang (attack), jurus (skill), bertahan (defend) dan menghindar (jump). 


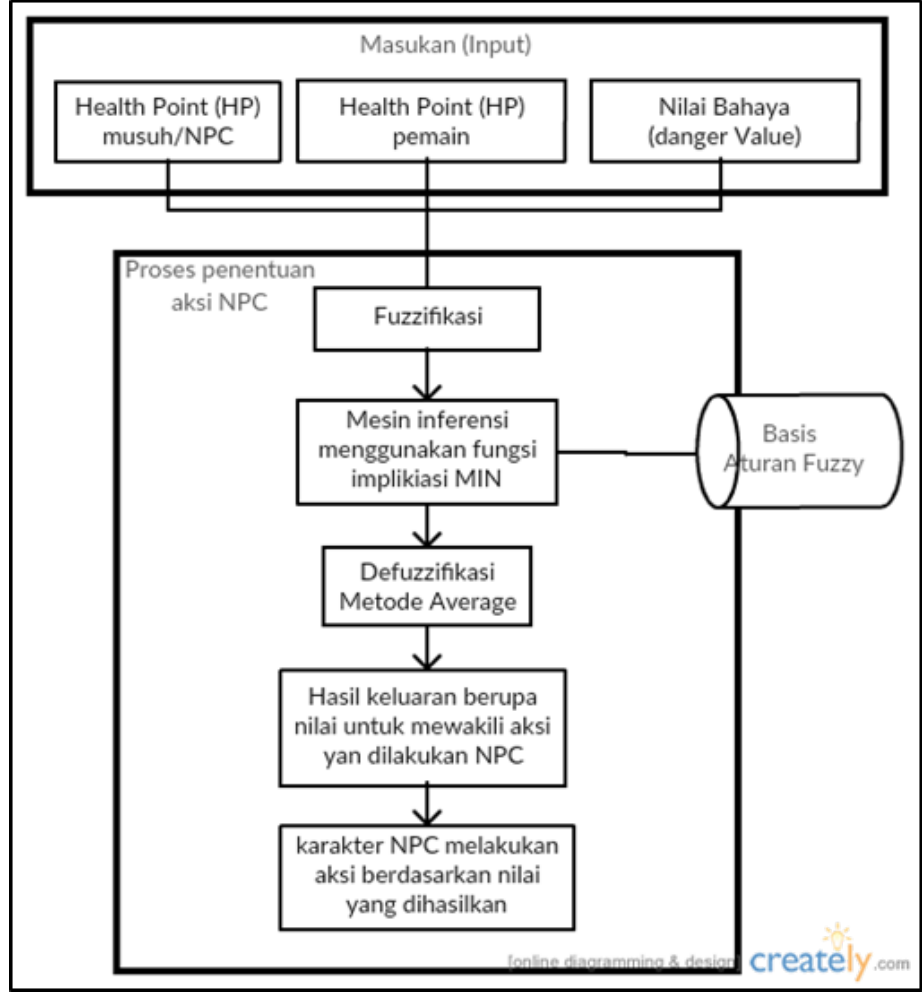

Gambar 1. Alur penentuan aksi karakter NPC

Berdasarkan Gambar 1, terdapat 3 buah nilai masukan yang akan digunakan pada tahap fuzzifikasi yaitu:

1. Health Point (HP) Musuh/NPC.

Merupakan suatu variabel untuk menentukan sisa energi kehidupan dari karakter musuh/NPC. Nilai HP ini akan diwakili dalam bentuk persentasi antara 0 hingga 100. Hal tersebut dilakukan karena nilai maksimal HP masing-masing karakter berbeda-beda. Setiap kali musuh terkena serangan oleh pemain, maka variabel ini akan berkurang hingga mencapai 0 . Apabila nilai sudah mencapai 0 , maka karakter musuh akan mati.

2. Health Point (HP) Pemain.

Merupakan suatu variabel untuk menentukan sisa energi kehidupan dari karakter pemain. Nilai HP ini akan diwakili dalam bentuk persentasi antara 0 hingga 100. Hal tersebut dilakukan karena nilai maksimal HP masing-masing karakter berbeda-beda. Setiap kali pemain terkena serangan oleh musuh, maka variabel ini akan berkurang hingga mencapai 0 . Apabila nilai sudah mencapai 0, maka karakter pemain akan mati.

3. Danger Value (Nilai Bahaya).

Merupakan variabel yang menandakan nilai bahaya yang dilakukan oleh karakter pemain, setiap kali karakter pemain melakukan sebuah aksi seperti menyerang, jurus, bertahan dan lain-lain nilai ini akan selalu berubah sesuai kondisi. Nilai ini akan juga digunakan sebagai indikasi seberapa besar ancaman bahaya terhadap karakter musuh.

Ketiga variabel masukan diatas akan digunakan dalam sistem fuzzy yang terdapat 3 proses utama yaitu:

1. Fuzzifikasi.

Pada tahap ini nilai pada variabel masukan Health Point dan nilai bahaya akan dirubah menjadi derajat keanggotaan pada masing-masing himpunan fuzzy dengan menggunakan fungsi keanggotaan. Dari derajat kenggotaan tersebut nantinya akan digunakan dalam perhitungan pada mesin inferensi. 
2. Mesin Inferensi.

Operasi yang dilakukan terhadap himpunan fuzzy berdasarkan basis aturan fuzzy dalam bentuk "IF ... THEN". Nilai-nilai dari derajat keanggotaan hasil dari fuzzifikasi akan dilakukan operasi sesuai dengan aturan yang sudah dibentuk. Aturan tersebut menggunakan metode fuzzy sugeno ordo 0 sehingga nilai konsekuen dari aturan yang didapat adalah nilai konstanta tegas. Operasi yang dilakukan dalam mengolah nilai himpunan fuzzy menggunakan fungsi implikasi MIN dengan menggunakan operasi logika AND.

3. Defuzzifikasi.

Untuk mendapatkan suatu hasil keluaran berupa nilai tegas (crisp) dari perhitungan pada mesin inferensi digunakan metode rata-rata (average). Nilai tersebut yang akan digunakan sebagai ukuran untuk mewakili dari aksi yang dilakukan oleh karakter musuh/NPC.

\subsection{Grafik Fungsi Keanggotaan}

Terdapat 3 fungsi keanggotaan yang digunakan pada tahap fuzzifikasi yaitu:

1. Fungsi Keanggotan Health Point (HP)

Gambar 2 merupakan bentuk grafik fungsi keanggotaan dari parameter health point. Pada fungsi keangggotaan health point rentang nilai yang digunakan antara 0 sampai dengan 100 . Nilai tersebut merupakan persentasi dari atribut health point yang dimiliki setiap karakter. Karena setiap karakter mempunyai nilai health point yang berbeda-beda sehingga perlu dikonversi ke dalam bentuk persen. Parameter HP juga digunakan oleh Harisa dan Fathurochman dalam penelitiannya sebagai masukan dalam sistem fuzzy [10] [11].

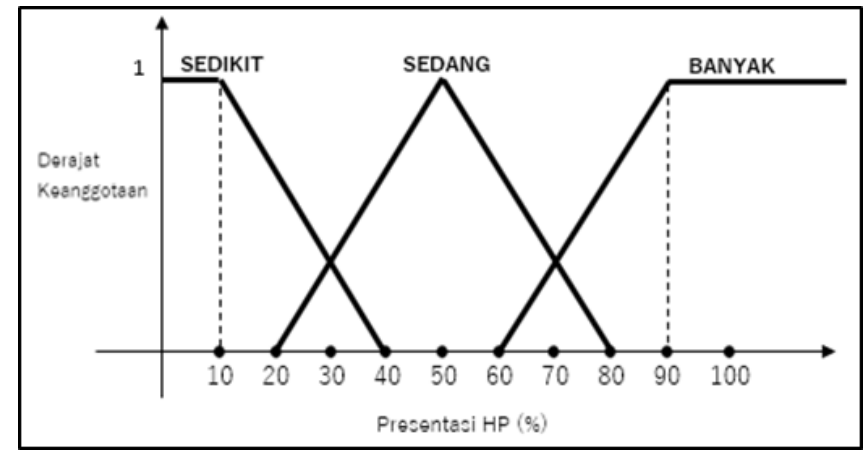

Gambar 2. Grafik fungsi keanggotaan HP

2. Fungsi Keanggotaan Nilai Bahaya (Danger Value).

Pada fungsi keanggotaan nilai bahaya rentang nilai yang digunakan adalah antara 0 hingga 20. Nilai bahaya ini merupakan indikasi ancaman yang dialami oleh karakter musuh. Nilai bahaya ini akan selalu berubah nilainya sesuai dengan aksi yang dilakukan oleh karakter pemain yang nantinya akan berpengaruh terhadap aksi yang dilakukan oleh karakter musuh/NPC. Untuk grafik fungsi keanggotaan dapat dilihat pada Gambar 3.

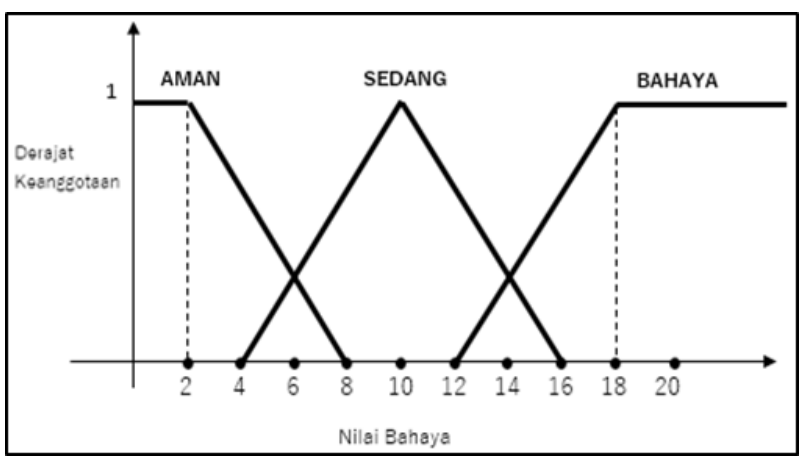

Gambar 3. Grafik fungsi keanggotaan danger value 


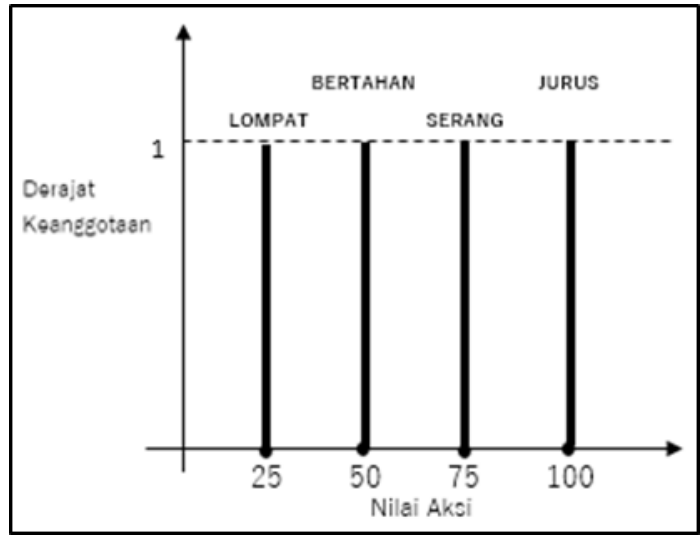

Gambar 4. Grafik fungsi keanggotaan aksi karakter NPC

3. Fungsi Keanggotaan Aksi Musuh/NPC

Grafik pada gambar 4 menunjukan kurva singleton untuk mewakili dari aksi yang dilakukan karakter musuh dengan rentang antara 0 hingga 100. Untuk aksi lompat atau menghindari diwakili oleh nilai 25, bertahan benilai 50, menyerang bernilai 75 dan jurus bernilai 100 . Nilai-nilai tersebut yang akan menjadi hasil konsekuen berupa konstanta pada basis pengetahuan aturan-aturan yang dibentuk.

\subsection{Aturan Fuzzy}

Pada Tabel 1 menunjukan basis pengetahuan aturan-aturan pada karakter NPC untuk menentukan aksi yang telah dibentuk untuk proses perhitungan pada mesin inferensi. Jumlah aturan yang terbentuk dapat dihitung dari banyaknya himpunan pada masing-masing parameter. Untuk parameter HP musuh dan pemain terdiri dari 3 himpunan. Sedangkan parameter danger value terdiri dari 3 himpunan. Sehingga jumlah aturan yang dapat dibentuk adalah $3 \times 3 \times 3=27$. Selain itu pada saat proses defuzzifikasi akan menghasilkan nilai aksi yang akan menentukan tindakan yang dilakukan karakter NPC sehingga perlu dibuat batasan nilai berupa kondisi yaitu:
a. Nilai aksi $>0$ dan nilai aksi $<=25$, maka aksi yang dilakukan adalah menghindar (jump).
b. Nilai aksi $>25$ dan nilai aksi $<=50$, maka aksi yang dilakukan adalah bertahan (defend).
c. Nilai aksi $>50$ dan nilai aksi $<=75$, maka aksi yang dilakukan adalah serang (attack).
d. Nilai aksi $>75$, maka aksi yang dilakukan adalah jurus (skill).

Tabel 1. Aturan fuzzy

\begin{tabular}{|l|c|c|c|c|c|}
\hline \multicolumn{2}{|c|}{} & \multirow{2}{*}{ HP Pemain } & \multicolumn{3}{|c|}{ Nilai Bahaya } \\
\cline { 3 - 6 } & & Aman & Sedang & Bahaya \\
\hline \multirow{4}{*}{ HP Musuh } & Sedikit & Sedikit & Jurus & Jurus & Jurus \\
\cline { 3 - 6 } & \multirow{3}{*}{ Sedang } & Sedang & Jurus & Jurus & Bertahan \\
\cline { 3 - 6 } & Banyak & Jurus & Menghindar & Bertahan \\
\cline { 3 - 6 } & Sedikit & Serang & Menghindar & Bertahan \\
\cline { 3 - 6 } & Sedang & Serang & Menghindar & Bertahan \\
\cline { 3 - 6 } & Banyak & Serang & Menghindar & Bertahan \\
\cline { 3 - 6 } & \multirow{3}{*}{ Banyak } & Sedikit & Serang & Serang & Bertahan \\
\cline { 3 - 6 } & & Sedang & Serang & Serang & Bertahan \\
\cline { 3 - 6 } & Banyak & Serang & Serang & Bertahan \\
\hline
\end{tabular}


Citec Journal, Vol. 4, No. 3, Mei 2017 - Juli 2017

ISSN: 2460-4259

\section{HASIL DAN PEMBAHASAN}

\subsection{Analisa Hasil Perhitungan}

Dalam penelitian yang dilakukan oleh Wicaksono dan Purba pada tahap pengujiannya dengan memberikan nilai parameter yang berbeda-beda [9][12]. Pada pengujian ini akan diambil sejumlah sampel data hasil keluaran dari perhitungan sistem fuzzy berdasarkan nilai dari ketiga parameter yang diberikan. Untuk parameter health point musuh dan pemain nilai yang diambil adalah 0, 15, 30, 45, 60, 75 dan 90. Sedangkan untuk parameter nilai bahaya diambil nilai 0, 2, 4, $6,8,10,12,14,16$ dan 18. Apabila ketiga nilai parameter tersebut saling dipasangkan maka akan terbentuk 490 data. Sehingga didapat hasil perhitungan yang dapat dilihat pada tabel 2.

Tabel 2. Hasil Keluaran Sistem Fuzzy

\begin{tabular}{|c|c|c|c|c|c|c|c|c|c|c|c|}
\hline \multirow{2}{*}{$\begin{array}{c}\text { HP } \\
\text { ENEMY }\end{array}$} & \multirow{2}{*}{$\begin{array}{c}\text { HP } \\
\text { PLAYER }\end{array}$} & \multicolumn{10}{|c|}{ DANGER VALUE } \\
\hline & & $\mathbf{0}$ & 2 & 4 & 6 & 8 & 10 & 12 & 14 & 16 & 18 \\
\hline \multirow{7}{*}{$\mathbf{0}$} & $\mathbf{0}$ & 100 & 100 & 100 & 100 & 100 & 100 & 100 & 100 & 100 & 100 \\
\hline & 15 & 100 & 100 & 100 & 100 & 100 & 100 & 100 & 100 & 100 & 100 \\
\hline & 30 & 100 & 100 & 100 & 100 & 100 & 100 & 100 & 88 & 75 & 75 \\
\hline & 45 & 100 & 100 & 100 & 100 & 100 & 100 & 100 & 75 & 50 & 50 \\
\hline & 60 & 100 & 100 & 100 & 100 & 100 & 100 & 100 & 75 & 50 & 50 \\
\hline & 75 & 100 & 100 & 100 & 75 & 44 & 44 & 44 & 50 & 50 & 50 \\
\hline & 90 & 100 & 100 & 100 & 63 & 25 & 25 & 25 & 38 & 50 & 50 \\
\hline \multirow{7}{*}{15} & $\mathbf{0}$ & 100 & 100 & 100 & 100 & 100 & 100 & 100 & 100 & 100 & 100 \\
\hline & 15 & 100 & 100 & 100 & 100 & 100 & 100 & 100 & 100 & 100 & 100 \\
\hline & 30 & 100 & 100 & 100 & 100 & 100 & 100 & 100 & 88 & 75 & 75 \\
\hline & 45 & 100 & 100 & 100 & 100 & 100 & 100 & 100 & 75 & 50 & 50 \\
\hline & 60 & 100 & 100 & 100 & 100 & 100 & 100 & 100 & 75 & 50 & 50 \\
\hline & 75 & 100 & 100 & 100 & 75 & 44 & 44 & 44 & 50 & 50 & 50 \\
\hline & 90 & 100 & 100 & 100 & 63 & 25 & 25 & 25 & 38 & 50 & 50 \\
\hline \multirow{7}{*}{30} & 0 & 88 & 88 & 88 & 75 & 63 & 63 & 63 & 69 & 75 & 75 \\
\hline & 15 & 88 & 88 & 88 & 75 & 63 & 63 & 63 & 69 & 75 & 75 \\
\hline & 30 & 88 & 88 & 88 & 75 & 63 & 63 & 63 & 63 & 63 & 63 \\
\hline & 45 & 88 & 88 & 88 & 75 & 63 & 63 & 63 & 56 & 50 & 50 \\
\hline & 60 & 88 & 88 & 88 & 75 & 63 & 63 & 63 & 56 & 50 & 50 \\
\hline & 75 & 88 & 88 & 88 & 63 & 38 & 38 & 38 & 44 & 50 & 50 \\
\hline & 90 & 88 & 88 & 88 & 56 & 25 & 25 & 25 & 38 & 50 & 50 \\
\hline \multirow{7}{*}{45} & 0 & 75 & 75 & 75 & 50 & 25 & 25 & 25 & 38 & 50 & 50 \\
\hline & 15 & 75 & 75 & 75 & 50 & 25 & 25 & 25 & 38 & 50 & 50 \\
\hline & 30 & 75 & 75 & 75 & 50 & 25 & 25 & 25 & 38 & 50 & 50 \\
\hline & 45 & 75 & 75 & 75 & 50 & 25 & 25 & 25 & 38 & 50 & 50 \\
\hline & 60 & 75 & 75 & 75 & 50 & 25 & 25 & 25 & 38 & 50 & 50 \\
\hline & 75 & 75 & 75 & 75 & 50 & 25 & 25 & 25 & 38 & 50 & 50 \\
\hline & 90 & 75 & 75 & 75 & 50 & 25 & 25 & 25 & 38 & 50 & 50 \\
\hline \multirow{7}{*}{60} & 0 & 75 & 75 & 75 & 50 & 25 & 25 & 25 & 38 & 50 & 50 \\
\hline & 15 & 75 & 75 & 75 & 50 & 25 & 25 & 25 & 38 & 50 & 50 \\
\hline & 30 & 75 & 75 & 75 & 50 & 25 & 25 & 25 & 38 & 50 & 50 \\
\hline & 45 & 75 & 75 & 75 & 50 & 25 & 25 & 25 & 38 & 50 & 50 \\
\hline & 60 & 75 & 75 & 75 & 50 & 25 & 25 & 25 & 38 & 50 & 50 \\
\hline & 75 & 75 & 75 & 75 & 50 & 25 & 25 & 25 & 38 & 50 & 50 \\
\hline & 90 & 75 & 75 & 75 & 50 & 25 & 25 & 25 & 38 & 50 & 50 \\
\hline
\end{tabular}


Tabel 2. Lanjutan.

\begin{tabular}{|c|c|c|c|c|c|c|c|c|c|c|c|}
\hline \multirow{2}{*}{$\begin{array}{c}\text { HP } \\
\text { ENEMY }\end{array}$} & \multirow{2}{*}{$\begin{array}{c}\text { HP } \\
\text { PLAYER }\end{array}$} & \multicolumn{10}{|c|}{ DANGER VALUE } \\
\hline & & $\mathbf{0}$ & 2 & 4 & 6 & 8 & 10 & 12 & 14 & 16 & 18 \\
\hline \multirow{7}{*}{75} & $\mathbf{0}$ & 75 & 75 & 75 & 67 & 62 & 62 & 62 & 54 & 50 & 50 \\
\hline & 15 & 75 & 75 & 75 & 67 & 62 & 62 & 62 & 54 & 50 & 50 \\
\hline & 30 & 75 & 75 & 75 & 67 & 58 & 58 & 58 & 54 & 50 & 50 \\
\hline & 45 & 75 & 75 & 75 & 67 & 62 & 62 & 62 & 54 & 50 & 50 \\
\hline & 60 & 75 & 75 & 75 & 67 & 62 & 62 & 62 & 54 & 50 & 50 \\
\hline & 75 & 75 & 75 & 75 & 65 & 58 & 58 & 58 & 52 & 50 & 50 \\
\hline & 90 & 75 & 75 & 75 & 67 & 62 & 62 & 62 & 54 & 50 & 50 \\
\hline \multirow{7}{*}{90} & $\mathbf{0}$ & 75 & 75 & 75 & 75 & 75 & 75 & 75 & 62 & 50 & 50 \\
\hline & 15 & 75 & 75 & 75 & 75 & 75 & 75 & 75 & 62 & 50 & 50 \\
\hline & 30 & 75 & 75 & 75 & 75 & 75 & 75 & 75 & 63 & 50 & 50 \\
\hline & 45 & 75 & 75 & 75 & 75 & 75 & 75 & 75 & 62 & 50 & 50 \\
\hline & 60 & 75 & 75 & 75 & 75 & 75 & 75 & 75 & 62 & 50 & 50 \\
\hline & 75 & 75 & 75 & 75 & 75 & 75 & 75 & 75 & 63 & 50 & 50 \\
\hline & 90 & 75 & 75 & 75 & 75 & 75 & 75 & 75 & 62 & 50 & 50 \\
\hline
\end{tabular}

Pada Tabel 2 untuk aksi serang ditandai dengan warna biru, untuk aksi bertahan ditandai dengan warna ungu, aksi jurus ditandai dengan warna kuning dan aksi menghindar ditandai dengan warna hijau. Untuk jumlah dari masing-masing aksinya dapat dilihat pada tabel 3.

Tabel 3: Jumlah presentasi nilai aksi

\begin{tabular}{|l|r|r|}
\hline \multicolumn{1}{|c|}{ Aksi } & Jumlah & \multicolumn{1}{c|}{ Presentasi } \\
\hline A (ATTACK) & 199 & $40,61 \%$ \\
\hline D (DEFEND) & 123 & $25,10 \%$ \\
\hline S (SKILL) & 117 & $23,88 \%$ \\
\hline J (JUMP) & 51 & $10,41 \%$ \\
\hline TOTAL & $\mathbf{4 9 0}$ & $\mathbf{1 0 0 , 0 0 \%}$ \\
\hline
\end{tabular}

Pada Tabel 3 terlihat bahwa aksi menyerang lebih dominan dengan persentasi sebesar 40,61\%. Kemudian urutan kedua terdapat aksi bertahan sebanyak 25,10\%, urutan ketiga aksi jurus sebanyak $23,88 \%$ dan urutan terakhir yaitu lompat sebanyak $10,41 \%$. Untuk lebih detailnya dapat ditampilkan dalam bentuk diagram pada Gambar 5.

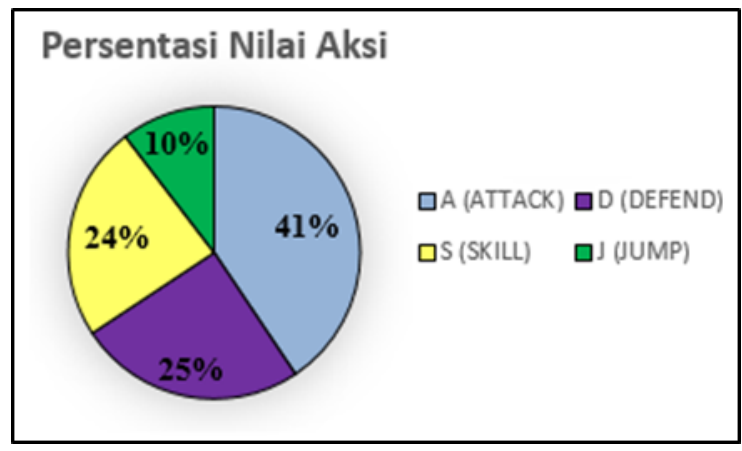

Gambar 5. Diagram persentasi nilai aksi

Apabila data pada Tabel 2 dibandingkan dengan aturan pada Tabel 1 dapat dilihat bahwa pola yang dibentuk terhadap keduanya akan sama. Sehingga dapat diambil kesimpulan bahwa aksi yang dihasilkan dari sistem fuzzy sesuai dengan tabel aturan yang sudah dibentuk 


\subsection{Analisa Kinerja}

Analisa kinerja digunakan untuk membandingkan seberapa besar biaya waktu eksekusi dan konsumsi CPU yang dibutuhkan dalam melakukan 1 kali perhitungan. Metode fuzzy akan dibandingkan dengan menggunakan metode sederhana yaitu menggunakan bilangan acak (random) untuk menentukan aksi yang dilakukan musuh. Pembagian masing-masing aksi mempunyai probabilitas yang sama yaitu sebesar 25\%. Hasil dari pengujian sebanyak 10 kali terhadap karakter musuh dapat dilihat pada tabel 4.

Tabel 4. Perbandingan waktu eksekusi

\begin{tabular}{|c|c|c|}
\hline No & Fuzzy & Random \\
\hline 1 & 0,001442 & 0,000191 \\
\hline 2 & 0,000034 & 0,000004 \\
\hline 3 & 0,000023 & 0,000000 \\
\hline 4 & 0,000027 & 0,000004 \\
\hline 5 & 0,000042 & 0,000004 \\
\hline 6 & 0,000023 & 0,000004 \\
\hline 7 & 0,000023 & 0,000004 \\
\hline 8 & 0,000031 & 0,000004 \\
\hline 9 & 0,000027 & 0,000004 \\
\hline 10 & 0,000027 & 0,000000 \\
\hline $\begin{array}{c}\text { Rata-Rata } \\
\text { Waktu }\end{array}$ & $\begin{array}{c}\mathbf{0 , 0 0 0 1 6 9 9} \\
\text { detik }\end{array}$ & $\begin{array}{c}\mathbf{0 , 0 0 0 0 2 1 9} \\
\text { detik }\end{array}$ \\
\hline
\end{tabular}

Dari kedua metode diatas terlihat bahwa hasil rata-rata waktu eksekusi untuk 10 kali percobaan menggunakan metode random memiliki waktu eksekusi yang lebih sedikit daripada metode fuzzy. Hal tersebut disebabkan karena proses pehitungan yang dilakukan metode fuzzy lebih kompleks dibandingkan dengan metode random sehingga waktu eksekusi yang dibutuhkan lebih lama.

Selain itu pengujian juga dilakukan dengan menggunakan fitur yang terdapat dalam game engine yang digunakan yaitu profiler. Fitur tersebut berguna untuk mengukur kinerja dari seluruh aspek yang dalam di dalam permainan seperti grafik, kode program, suara, penggunaan memori dan lain-lain.

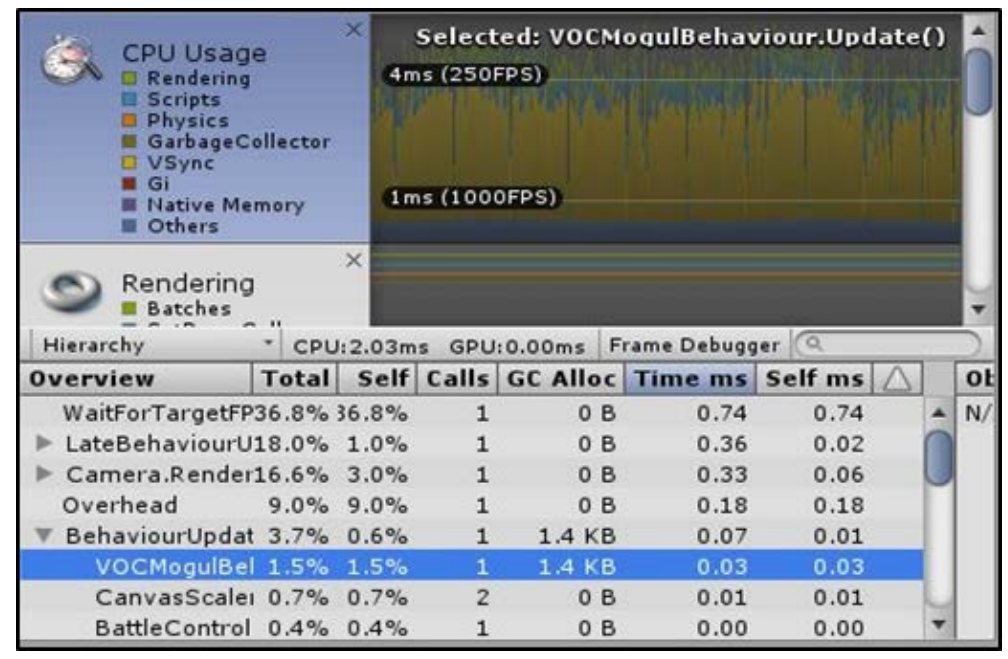

Gambar 6. Hasil kinerja menggunakan fuzzy

Pada gambar 6 terlihat bahwa bagian behaviour update untuk script “VOCMogulBehaviour” menunjukan bahwa aksi tersebut mengkonsumsi CPU sebesar 1,5\%. 


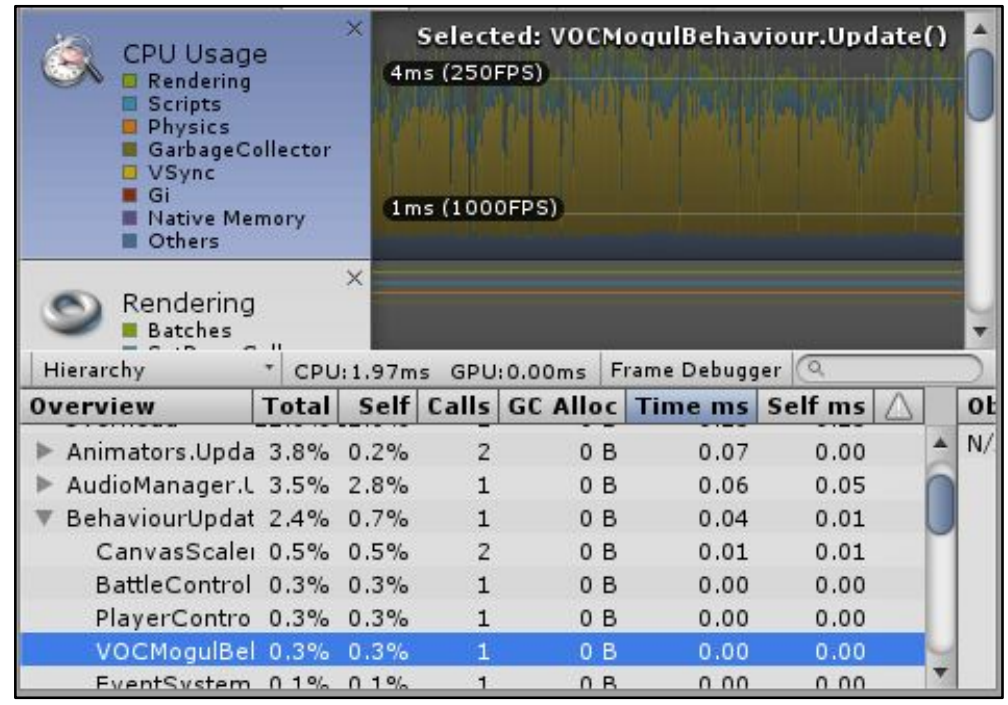

Gambar 7. Hasil kinerja menggunakan random

Sedangkan pada Gambar 7 merupakan hasil dari analisa terhadap metode random, terlihat bahwa konsumsi $C P U$ sebesar $0.3 \%$.

Dari kedua pengujian kinerja di atas dapat disimpulkan bahwa untuk analisa kinerja, metode random memakan waktu eksekusi dan konsumsi CPU lebih sedikit dari metode fuzzy. Namun, jika dilihat dari nilai aksi yang dihasilkan metode fuzzy lebih baik daripada random karena metode random akan menghasilkan nilai yang acak sehingga karakter NPC akan berperilaku acak dan tidak dapat menyesuaikan dengan kondisi yang sedang dihadapi. Selain itu besarnya biaya eksekusi waktu dan konsumsi CPU tidak terlalu berdampak pada kinerja dalam pemainan karena nilainya yang kecil sehingga masih dapat ditoleransi.

\section{KESIMPULAN}

Dari penelitian yang telah dilakukan maka dapat diambil beberapa kesimpulan yaitu:

1. Permainan genre action-RPG berhasil dibuat dengan mengusung tema sejarah geger pacinan.

2. Beberapa aset seperti karakter musuh, pemain dan lingkungan latar belakang permainan telah dibuat sedemikian rupa sehingga sesuai dengan tema sejarah geger pacinan.

3. Metode fuzzy sugeno membuat karakter NPC atau musuh dapat melakukan aksi secara dinamis dengan menyesuaikan kondisi parameter health point musuh, health point pemain dan nilai bahaya.

4. Beberapa pengujian yang dilakukan terhadap aksi yang dilakukan karakter NPC sudah sesuai dengan aturan yang telah dibuat berasarkan kondisi dari nilai atribut HP musuh, HP pemain dan nilai bahaya.

5. Secara sederhana perilaku musuh akan cenderung betahan apabila nilai bahaya semakin tinggi dan kondisi HP musuh tersebut dalam keadaan kritis, sedangkan musuh akan cenderung menyerang jika kondisi HP musuh banyak dan nilai bahayanya rendah.

\section{SARAN}

Dalam penelitian ini terdapat beberapa hal yang dapat dikembangkan untuk dapat memperbaiki dan meningkatkan pada penelitian selanjunya yaitu:

1. Menambah kategori tingkat kesulitan sepeti mudah, sedang dan susah yang mempengaruhi tingkat kelincahan pergerakan karakter NPC dalam melakukan aksi. 
2. Menggunakan atau menggabungkan metode kecerdasan buatan lain yang dapat meningkatkan kualitas dan hasil keputusan yang lebih baik.

3. Penambahan beberapa fitur yang dapat mendukung dan membuat permainan lebih menarik dengan cara memberikan fitur sepeti potongan film pendek atau cut scene.

4. Menambahkan jumlah level dan musuh yang lebih bervariasi dan menarik sehingga dapat meningkatkan ketertarikan dan kepuasan dalam bermain.

\section{DAFTAR PUSTAKA}

[1] Ria, M., 2016, Mata Dunia, http://www.mataduniakami.id/2016/12/pengertian-atau-definisisejarah.html. diakses tanggal 4 Januari 2017.

[2] Novandri, B., 2013, Pengaruh Pemanfaatan Sumber Sejarah Lokal Daerah Sekitar Kota Tegal Terhadap Kesadaran Sejarah Siswa SMA Negeri Se-Kota Tegal, Skripsi, Fakultas Ilmu Sosial, Universitas Negeri Semarang, Semarang.

[3] Widagdo, H., Baltyra, 2013, Available, http://baltyra.com/2013/05/24/geger-pacinan-17401743-persekutuan-tionghoa-jawa-melawan-voc/, diakses tanggal 5 Januari 2017.

[4] Chowanda, A., Prasetio, Y. L., 2012, Perancangan Game Edukasi Bertemakan Sejarah Indonesia (Ken Arok dan Buto Ijo), Seminar Nasional SEMANTICS 2012, Jakarta, 14 Juli 2012.

[5] Lopes, R., Bidarra, R., 2011, Adaptivity Challenges in Games and Simulations: A Survey, IEEE Transactions on Computational Intelligence and AI in Games, No. 2, Vol. 3, Hal. 8599.

[6] Liarokapis, F., Debattista, K., Vourvopoulos, A., Petridis, P., dan Ene, A., 2014, Comparing interaction techniques for serious games through brain-computer interfaces: A user perception evaluation study, Entertainment Computing, No. 4, Vol, 5, Hal. 391-399.

[7] Yannakakis, G. N., Togelius, J., 2015, Artificial and Computational Intelligence in Games, IEEE Transactions on Computational Intelligence and AI in Games, No. 4, Vol. 7, Hal. 317 - 335.

[8] Yannakakis, G. N., 2012, Game AI Revisited, Proceedings of the 9th conference on Computing Frontiers, Cagliari, 15-17 Mei 2012.

[9] K. R. Purba, R. N. Hasanah, M. A. Muslim, 2013, Implementasi Logika Fuzzy Untuk Mengatur Perilaku Musuh dalam Game Bertipe Action-RPG, Jurnal EECCIS, No. 1, Vol. 7, Hal. 15 - 20.

[10] Harisa, A. B., Haryanto, H., Santoso, H. A., 2016, Model Tingkat Kesulitasn Dinamis Berbasis Logika Fuzzy Pada Game Wayang Ramayana, Seminar Nasional Teknologi Informasi dan Multimedia 2016, Yogyakarta, 6-7 Februari 2012.

[11] Fathurochman, D., Witanti, W., Yuniarti, R., Perancangan Game Turn Based Strategy Menggunakan Logika Fuzzy dan Naive Bayes Classifier, Seminar Nasional Informatika 2014 (semnasIF 2014), Yogyakarta, 12 Agustus 2014.

[12] Wicaksono, A., Hariadi, M., Nugroho, S. M. S., 2013, Strategi Menyerang NPC Game FPS Menggunakan Fuzzy Finite State Machine, Seminar Nasional Teknologi Informasi dan Multimedia 2013, Yogyakarta, 19 Januari 2013.

[13] Kurniawan, H., 2014, Aplikasi Permainan Gomoku dengan Algoritma Negamax dan Alpha-Beta Search, Creative Information Technology Journal (CITEC Journal), No. 3, Vol. 1, Hal. 231-242. 
[14] Haryanto, H., Kardianawati, A., Rosyidah, U., 2017, Agen Cerdas Untuk Perilaku Reward Appreciative Learning Dalam Game Pendidikan Kewirausahaan, Techno.COM, No. 3, Vol. 16, Hal. 325-336. 